\title{
NON-COMPETITION CLAUSE DALAM PERJANJIAN KERJA
}

\author{
Oleh \\ Rizky Amalia*
}

\begin{abstract}
ABSTRAK
Non-competition clause biasanya terdapat dalam suatu perjanjian kerja. Pemberlakuan non-competition clause memerlukan suatu pembatasan. Pembatasan suatunon-competition clause diperlukan dalam pemberlakuan klausula ini. Pelanggaran non-competition clause oleh pekerja yang menimbulkan kerugian bagi perusahaan dapat dilakukan suatu upaya hukum. Adapun upaya hukum yang dapat ditempuh oleh perusahaan tersebut adalah melalui jalur pengadilan maupun di luar pengadilan. Jika non-competition clause dirasa sangat membatasi hak pekerja atau dengan kata lain klausula ini tidak dalam batas kewajaran, pekerja tersebut mempunyai hak untuk mengajukan keberatan. Pekerja dapat mengajukan gugatan ke Pengadilan Negeri setempat. Mengenai keberatan terhadap noncompetition clause ini dapat dikategorikan sebagai perselisihan kepentingan.
\end{abstract}

Kata Kunci : non-competition clause, perjanjian kerja

\section{Pendahuluan}

Bekerjamerupakansalahsatukebutuhan manusia yang mempunyai peranan penting dalam kehidupan. Pasal 28 D ayat (2) Undang-undang Dasar 1945 (selanjutnya disebut dengan UUD 1945) ditegaskan : " Setiap orang berhak untuk bekerja serta mendapat imbalan dan perlakuan yang adil dan layak dalam hubungan kerja." Pengaturan tersebut memberikan pengertian bahwa bekerja merupakan salah satu bagian dari hak asasi manusia yang dijamin oleh konstitusi, dimana setiap manusia diberikan hak untuk bekerja serta bebas memilih pekerjaan yang sesuai dengan kemampuan yang dimiliki.
Pengaturan serupa juga di atur dalam Undang-Undang Nomor 13 Tahun 2003 tentangKetenagakerjaan(selanjutnyadisebut dengan UU Ketenagakerjaan). Prinsipnya, UU Ketenagakerjaan memberikan hak dan kesempatan yang sama bagi tenaga kerja untuk memilih, mendapatkan atau pindah pekerjaan dan memperoleh penghasilan yang layak baik di dalam maupun di luar negeri. ${ }^{1}$ Hal tersebut dikuatkan oleh Pasal 38 ayat (2) Undang-undang Nomor 39 Tahun 1999 tentang Hak Asasi Manusia (selanjutnya disebut dengan UU HAM) yang menyebutkan bahwa setiap orang

\footnotetext{
*WINS \& Partners Law Firm, rizkyamalia07@gmail. com

1 Chandra Kurniawan, dalam artikel "Menyoal Non Competition Clause dalam Perjanjian Kerja”, www. purcahyo.blogspot.com, dikunjungi pada Juli 2010, h.1
} 
berhak dengan bebas memilih pekerjaan yang disukainya dan berhak pula atas syaratsyarat ketenagakerjaan yang adil.

Terdapat dua pihak dalam hubungan ketenagakerjaan yaitu pekerja dan majikan. ${ }^{2}$ Hubungan keduanya merupakan suatu hubungan yang menghasilkan suatu perikatan. Suatu perikatan adalah suatu perhubungan hukum antara dua orang atau dua pihak, berdasarkan mana pihak yang satu berhak menuntut sesuatu hal dari pihak yang lain, dan pihak yang lain berkewajiban untuk memenuhi tuntutan itu. ${ }^{3}$ Perjanjian yang dibuat antara pekerja dan perusahaan lazimnya disebut dengan perjanjian kerja. Suatu perjanjian kerja harus didasarkan pada ketentuan-ketentuan yang terdapat dalam UU Ketenagakerjaan dan kembali apada aturan-aturan umum tentang perjanjian apabila tidak diatur.

Biasanya pekerja diminta untuk menandatangani suatu perjanjian kerja yang telah disiapkan oleh perusahaan. Umumnya, tidak ada negosiasi yang dilakukan pekerja terhadap klausulaklausula yang diperjanjikan. Hal ini dikarenakan keduanya tidak memiliki posisi tawar yang relatif seimbang. Terkadang pekerja tidak mengetahui dan memeriksa secara seksama klausula-klausula yang nantinya akan menjadi prestasinya. Hal ini memungkinkan terjadinya kerugian terhadap kedua belah pihak jika suatu saat salah satu pihak melakukan pelanggaran terhadap isi perjanjian.

\footnotetext{
${ }^{2}$ Lihat Pasal 1 angka 4, 5 dan 6 UU Ketenagakerjaan 3 Subekti, Hukum Perjanjian, Intermasa, Jakarta, 2005, h. 1
}

Beberapa perjanjian kerja ada yang memuat suatu non-competition clause di dalam perjanjiannya tetapi, tidak semua perjanjian kerja mencantumkan klausula tersebut. Dalam klausula ini diatur bahwa pekerja setuju untuk tidak akan bekerja sebagai karyawan atau agen perusahaan yang dianggap sebagai pesaing atau bergerak pada bidang usaha yang sama untuk periode atau jangka waktu tertentu setelah tanggal pemberhentian atau pemutusan hubungan kerja.

4 Pencantuman klausula tersebut biasanya dilakukan oleh perusahaanperusahaan besar yang memiliki pesaing, begitu pula dalam industri perbankan.

Adapun maksud dari perusahaan mencantumkan klausula tersebut, digunakan sebagai perlindungan perusahaan dari kompetitornya. Hal ini juga terkait dengan rahasia dagang yang diakui oleh hukum Indonesia dengan Undang-undang Nomor 30 Tahun 2000 tentang Rahasia Dagang (selanjutnya disebut dengan UU Rahasia Dagang). Dengan adanya pencantuman non-competition clause diharapkan pekerja tidak membocorkan rahasia dagang maupun segala informasi yang bersifat rahasia kepada perusahaan pesaing. Trade secret (rahasia dagang) pada dasarnya adalah informasi dalam bentuk apapun yang mempunyai nilai ekonomis karena kerahasiaannya dan dilakukan upaya-upaya untuk tetap menjaga kerahasiaannya. $^{5}$

Suatu perjanjian akan menimbulkan

\footnotetext{
${ }^{4}$ Chandra Kurniawan, op.cit, h. 1

${ }^{5}$ Rahmi Jened dalam artikel : Perlindungan "Trade Secret" (Rahasia Dagang) dalam Rangka Persetujuan TRIPS
} 
akibat hukum bagi pihak-pihak yang terikat di dalamnya. Jika dalam perjanjian kerja terdapat suatu non-competition clause, tentunya dalam hal ini pekerja yang telah menandatangani perjanjian kerja berkewajiban untuk memenuhi klausula tersebut. Jadi, jika pekerja tidak memenuhi kewajibannya dalam pelaksanaan klausula tersebut, hal ini memungkinkan pekerja telah melakukan pelanggaran perjanjian kerja. Tentunya, jika hal tersebut dapat dikategorikan sebagai pelanggaran perjanjian, akan membawa kerugian bagi perusahaan tempat pekerja bekerja. Lebih lanjut, hal ini menimbulkan suatu pertanyaan tentang dapat atau tidaknya klausula tersebut dijadikan dasar bagi perusahaan untuk menuntut prestasi.

Pada kenyataan dijumpai beberapa pekerja yang tidak memenuhi klausula tersebut dengan alasan membutuhkan pekerjaan untuk memenuhi kebutuhannya. Jika dikaitkan bahwa bekerja adalah hak asasi setiap manusia, tentunya klausula tersebut tidak bisa dijadikan sebagai pengikat untuk menghalangi setiap orang memilih atau menerima pekerjaan, tetapi tidak dilaksanakannya klausula tersebut akan mengancam posisi perusahaan lama dengan pesaingnya. Berdasarkan latar belakang di atas, perjanjian kerja yang memuat noncompetition clause menarik untuk dikaji lebih mendalam dengan dua isu pokok yaitu :keabsahan non-competition clause dalam perjanjian kerja; dan upaya hukum atas pelanggaran terhadap non-competition clause dalam perjanjian kerja.

\section{KEABSAHAN NON-COMPETITION CLAUSE DALAM PERJANJIAN KERJA}

\section{Hubungan Hukum Para Pihak dalam Perjanjian Kerja}

Hubungan hukum antara pekerja dengan perusahaan merupakan suatu hubungan kerja yang merupakan realisasi dari adanya suatu perjanjian kerja. Perjanjian kerja merupakan unsur utama lahirnya hubungan kerja. Dengan adanya hubungan kerja akan timbul hak dan kewajiban antara perusahaan dan pekerja. Hak dan kewajiban harus diatur secara jelas melalui peraturan perundang-undangan, perjanjian kerja, peraturan perusahaan, dan/atau perjanjian kerja bersama agar ada kepastian bagi kedua belah pihak untuk tercapainya hubungan kerja yang serasi dan harmonis antara perusahaan dan pekerja. Pasal 1 angka 15 UU Ketenagakerjaan disebutkan bahwa : "Hubungan kerja adalah hubungan antara pengusaha dengan pekerja/ buruh berdasarkan perjanjian kerja, yang mempunyai unsur pekerjaan, upah, dan perintah".

\section{Pengaturan Non-Competition Clause dalam Perjanjian Kerja}

Dimulainya suatu pekerjaan biasanya didahului dengan adanya suatu perjanjian kerja. Perjanjian kerja merupakan kesepakatan kedua belah pihak, namun dalam praktiknya perusahaan telah mempersiapkan draft perjanjian yang berisikan prestasi kedua belah pihak. Pekerja hanya diberikan kesempatan untuk membaca 
dan menyetujui semua klausula yang ada dalam perjanjian kerja tanpa terkecuali. Bagi pekerja, peluang untuk melakukan negosiasi terhadap isi perjanjian sangatlah kecil, bahkan hal tersebut bisa ditiadakan. Prinsip perusahaan dalam hal ini yaitu "take it or leave it", jika pekerja tidak setuju dengan isi perjanjian kerja, maka perusahaan akan mencari pekerja lainnya yang setuju dengan isi perjanjian yang ditawarkan perusahaan. Perjanjian kerja berisikan tentang segala hak dan kewajiban masingmasing para pihak. Muatan dalam perjanjian kerja telah diatur dalam Pasal 54 ayat (1) UU Ketenagakerjaan. ${ }^{6}$ Pembuatan suatu perjanjian kerja, dimungkinkan terdapat penambahan klausula-klausula lainnya. Salah satunya adalah mengenai noncompetition clause. Hanya perusahaanperusahaan yang memiliki kepentingan saja yang menambahkan klausula tersebut dalam suatu perjanjian kerja.

Black's Law dictionary mendefinisikan non-competition clause (dalam kamus disebut sebagai non-competition covenant) sebagai a promise usually in a sale-of business, partnership or employment contract, not to engage in the same type of business for a stated time in the same market as the buyer, partner or employer. ${ }^{7}$ Sedangkan dalam Wikipedia didefinisikan sebagai berikut :

"A non-compete clause or covenant not to compete (CNC), is a term used in contract law under which one party (usually an employee) agrees not to

\footnotetext{
${ }^{6}$ Lihat Pasal 54 ayat (1) UU Ketenagakerjaan

${ }^{7}$ Lihat Black's Law Dictionary
}

pursue similar profession or trade in competition against another party (usually the employer)", ${ }^{8}$

Pengertian di atas menyatakan bahwa non-competition clause tidak terbatas hanya kepada lingkup perjanjian saja. Non-competition clause biasanya meliputi beberapa hal seperti waktu dan geografis. Hal waktu artinya dalam durasi tertentu (biasanya 12 bulan) pekerja tidak boleh bergabung dengan semua pesaing perusahaan atau sejenisnya. Sedangkan berdasarkan geografis diartikan pekerja tidak bisa bergabung dengan perusahaan manapun dalam jarak $50 \mathrm{~km}$ dari perusahaan sebelumnya. ${ }^{9}$

Berikut ini contoh non-competition clause :

"For good consideration and as an inducement for

(Company) to employ

(Employee), the undersigned Employee hereby agrees not to directly or indirectly compete with the business of the Company and its successors and assigns during the period of employment and for a period of years following termination of employment and notwithstanding the cause or reason for termination.

The term "not compete" as used herein shall mean that the Employee shall not own, manage, operate, consult or be employed in a business substantially similar to or competitive with, the ${ }^{8}$ www.wikipedia.org dikunjungi pada 08/10/10 9 www.islam.net dikunjungi pada 10/10/10 
present business of the Company or such other business activity in which the Company may substantially engage during the term of employment". ${ }^{10}$

Di negara-negara Barat seperti Amerika, Belanda, Belgia, Jerman, Spanyol dan Perancis, klausula ini ditanggapi secara beragam. Hal ini berarti ada beberapa negara yang memperbolehkan klausula ini dimuat dalam perjanjian kerja, di samping itu juga ada beberapa negara yang tidak memperbolehkan pencantuman klausula tersebut dalam perjanjian kerja. Biasanya negara-negara yang memperbolehkan klausula ini memberikan pembatasanpembatasan sangat ketat seperti misalnya tidakbolehlebih dariwaktutertentu(biasanya 2 tahun), tidak boleh bertentangan dengan kepentingan publik, tidak menyebabkan perlindungan yang berlebihan terhadap suatu kegiatan usaha selain rahasia dagang serta tidak boleh menyebabkan pembatasan yang berlebihan sehingga menghambat pekerja tersebut kesulitan mencari nafkah. ${ }^{11}$

Sebagian besar pengaturan noncompetition clause menurut ketentuan hukum di beberapa negara dan beberapa putusan pengadilan menganggap bahwa klausula ini secara hukum mempunyai legal binding (kekuatan hukum mengikat). Tentunya hal ini tidak terlalu bebas, melainkan mempunyai batasan mengenai wilayah geografis dan periode waktu yang rasional. Pembatasan tersebut bertujuan untuk mencegah perusahaan yang dapat

\footnotetext{
${ }^{10} \underline{\text { www.employer-rights.com }}$ dikunjungi pada $12 / 10 / 10$

${ }^{11}$ Chandra Kurniawan, op. cit, h. 1
}

menyalahgunakan klausula ini untuk membatasi bahkan mencegah pekerja untuk bekerja di tempat lain.

\section{Non-Competition Clause menurut Ketentuan Hukum Indonesia}

Non-competition clause di berbagai Negara diberikan pembatasan-pembatasan dalam keberlakuannya. Ada yang dibatasi dengan suatu Undang-undang maupun dengan kebijakan publik. Berdasarkan ketentuan hukum perjanjian di Indonesia, maka suatu perjanjian adalah sah jika memenuhi empat syarat sebagaimana yang diatur dalam Pasal 1320 BW. Hal ini berkaitan dengan klausula-klausula yang dimuat dalam suatu perjanjian. Isi suatu perjanjian kerja telah diatur dalam UU Ketenagakerjaan secara tegas. Dalam perwujudannya, non-competition clause bisa merupakan bagian dari suatu perjanjian kerja atau dibuat secara terpisah dari perjanjian kerja. Tentunya jika klausula ini dicantumkan dalam perjanjian kerja maka harus merujuk pada ketentuan-ketentuan hukum yang berlaku.

Ketentuan hukum di Indonesia tidak mengatur secara tegas mengenai pengaturan maupun pembatasan suatu non-competition clause. Sebenarnya tidak ada satu ketentuan hukum pun berdasarkan hukum Indonesia yang secara tegas melarang pencantuman non-competition clause dalam perjanjian kerja selama para pihak sepakat menundukkan diri mereka terhadap klausula tersebut. 
Akibat Pencantuman Non-Competition Clause terhadap Perjanjian Kerja

Perjanjian kerja merupakan perjanjian yang memaksa (dwang contract) karena para pihak tidak dapat menentukan sendiri keinginannya dalam perjanjian. Hukum perjanjian yang mengatur ketentuan umum, sepanjang tidak diatur oleh hukum ketenagakerjaan berlaku dalam perjanjian kerja, tetapi bila undang-undang ketenagakerjaan telah mengaturnya maka ketentuan tersebut bersifat memaksa, artinya tidak dapat dikesampingkan. ${ }^{12} \mathrm{Hal}$ ini bukan berarti tidak dapat dibuat suatu kesepakatankesepakatan lain antara perusahaan dengan pekerja yang kemudian dapat dituangkan dalam perjanjian kerja tersebut. Prinsip kebebasan berkontrak tetap dapat berlaku sejauh mana penerapan prinsip tersebut tidak bertentangan dengan kaidah heteronom dalam hukum perburuhan.

Pencantuman non-competition clause dalam perjanjian kerja membawa pengaruh terhadap keabsahan dan pelaksanaan perjanjian tersebut. Keabsahan klausula ini membawa pengaruh terhadap pelaksanaan klausula tersebutyang merupakan kewajiban dari pihak pekerja. Aturan-aturan yang ada dalam UU Ketenagakerjaan dan juga dalam BW inilah yang dijadikan acuan dalam menganalisis keabsahan non-competition clause yang membawa akibat terhadap perjanjian kerja. Hal ini berkaitan dengan syarat obyektif suatu perjanjian dimana isi perjanjian tersebut yang menentukan keabsahan perjanjian yang berakibat pada

${ }^{12}$ Hardijan Rusli, Hukum Ketenagakerjaan, Ghalia Indonesia, Jakarta, 2004, h. 70 pelaksanaan perjanjian.

Terkait dengan obyek tertentu yang merupakan syarat obyektif keabsahan suatu perjanjian, maka pernyataan-pernyataan yang sifat dan luasnya sama sekali tidak dapat ditentukan, tidak mempunyai daya mengikat. 13 Non-competition clause mensyaratkan bahwa pekerja tidak diperbolehkan untuk bekerja di perusahaan pesaing setelah berhenti atau diberhentikan dari pekerjaannya. Untuk itu pembatasan mengenai obyek dalam klausula ini haruslah jelas. Jika suatu perusahaan yang berkepentingan mencantumkan klausula ini dalam perjanjian kerja tetapi tidak memberikan batasan yang jelas mengenai perusahaan mana saja yang dianggap sebagai pesaing, batas waktu maupun geografis maka dapat dikatakan bahwa klausula ini tidak mendeskripsikan secara jelas mengenai obyek tertentu. Sehingga hal ini membawa akibat klausula ini tidak sah dan tidak dapat dilaksanakan.

Syarat keempat dari keabsahan perjanjian yaitu causa yang diperbolehkan. Syarat ini dalam perjanjian kerja dimaksudkan bahwa pekerjaan yang diperjanjikan tidak bertentangan dengan ketertiban umum, kesusilaan dan peraturan perundang-undangan yang berlaku. Hal ini merupakan adopsi dari Pasal 1320 jis 1335 dan 1337 BW pengertian causa (sebab) sama sekali berbeda, dan kurang lazim. Disitu pengertian causa (sebab) menunjuk kepada hubungan tujuan (causa finalis). Jadi, causa (sebab) perjanjian adalah apa yang ingin dicapai oleh para pihak dengan

13 Ibid, h. 25 
perjanjian, yaitu tujuan perjanjian. ${ }^{14}$ Harus dilihat mengenai tujuan dari perusahaan yang mencantumkan non-competition clause dalam perjanjian kerja. Selama tujuan itu wajar dan dapat dibuktikan bahwa kepentingan tersebut harus dilindungi, dan tidak melakukan pembatasan hak secara berlebihan maka syarat causa yang diperbolehkan ini terpenuhi. Jika yang diinginkan para pihak (causa) tidak halal, yaitu bertentangan dengan undang-undang, kesusilaan atau "openbare orde" (cf. pasal 1337) yang dinilai menurut keadaan waktu penutupan perjanjian, maka perjanjian yang ingin mencapai ini, batal. ${ }^{15}$

\section{UPAYA HUKUM \\ PELANGGARAN TERHADAP NON- COMPETITION CLAUSE DALAM PERJANJIAN KERJA}

\section{Karakteristik Pelanggaran Non- Competition Clause dalam Perjanjian Kerja}

Hubungan kerja didasarkan pada suatu perjanjian kerja, dimana berakhirnya perjanjian kerja maka berakhir pulalah hubungan kerja tersebut. Hal ini berbeda dengan berlakunya non-competition clause, karena klausula ini mempunyai dayaberlaku setelah hubungan kerja berakhir. Klausula ini mengikat pekerja setelah diberhentikan atau berhenti dari pekerjaannya.

Setelah berakhirnya hubungan kerja, pekerja yang dalam perjanjian kerjanya dicantumkan suatu non-competition clause, makapekerja tersebutterikat denganklausula

\footnotetext{
14 Ibid

15 Ibid, h. 26
}

tersebut dimana daya berlakunya terjadi setelah hubungan kerja berakhir. Klausula ini merupakan klausula larangan karena berisi suatu prestasi untuk tidak berbuat sesuatu. Pekerja yang terikat dengan klausula ini dianggap memenuhi prestasi apabila dalam kurun waktu dan wilayah geografis yang telah ditentukan oleh perusahaan, pekerja tidak melakukan larangan yang telah diatur dalam klausula ini. Larangan tersebut berupa tidak diperbolehkannya seorang pekerja menerima pekerjaan dan bekerja di perusahaan yang menjadi pesaing atau bergerak pada bidang yang sama dengan perusahaan dimana pekerja tersebut bekerja sebelumnya. Hal ini dilarang karena adanya kekhawatiran dari perusahaan terhadap mantan pekerjanya tersebut membocorkan segala informasi penting perusahaan baik rahasia dagang, maupun informasi lainnya yang bersifat rahasia tanpa sepengetahuan. Terjadinya pengungkapan informasi yang dimiliki satu pihak lainnya tanpa diketahui oleh pihak pemilik informasi dapat menimbulkan kerugian bagi pemilik informasi tersebut. ${ }^{16}$

$$
\text { Pelanggaran terhadap non- }
$$
competition clause dalam praktiknya kerap terjadi.Pekerjaseringkalimengesampingkan adanya klausula tersebut karena pekerja tersebut beranggapan bahwa menerima atau memilih suatu pekerjaan merupakan hak asasi setiap manusia yang diatur dalam UUD 1945. Pelanggaran demikian tidak menjadi persoalan apabila perusahaan lama dimana pekerja tersebut bekerja dulu tidak

${ }^{16}$ www.blog.mybcshop.com dikunjungi pada $03 / 11 / 10$ 
mengalami kerugian akibat pelanggaran klausula ini oleh mantan pekerjanya. Hal ini berbeda apabila pelanggaran yang dilakukan oleh pekerja tersebut terhadap klausula ini membawa suatu ancaman dan kerugian bagi perusahaan yang mengikat pekerja tersebut dengan non-competition clause. Pengkategorikan pekerja telah melakukan pelanggaran terhadap noncompetition clause yaitu apabila pekerja mengungkapkan informasi perusahaan yang meliputi segala informasi yang bersifat rahasia maupun rahasia dagang tanpa sepengetahuan perusahaan pemilikinformasi untuk kepentingan perusahaan baru tempat ia bekerja sehingga menimbulkan kerugian bagi perusahaan lama tempat ia bekerja sebelumnya.

Jika hal tersebut tidak dilakukan oleh pekerja, maka tidak dipenuhinya prestasi tersebut tidak berakibat apa-apa dan pekerja dapat dikatakan tidak melakukan suatu pelanggaran. Biasanya pengetahuan, keterampilan, keahlian atau kemampuan mental yang didapat seorang pekerja di perusahaan lama tempat ia bekerja sebelumnya tidak termasuk ke dalam informasi rahasia dan boleh digunakan atau diterapkan di tempat kerja yang baru. Ada hal yang perlu diperhatikan, yaitu buruh dapat menggunakan informasi rahasia dari perusahaantempatnyabekerjadengancatatan tidak melanggar perjanjian kerahasiaan yang telah dilakukannya dengan perusahaan pemilik informasi rahasia tersebut. ${ }^{17}$

\section{Upaya Hukum terhadap Pelanggaran}

Non-Competition Clause dalam Perjanjian Kerja

Pelanggaran non-competition clause oleh pekerja yang menimbulkan kerugian bagi perusahaan dapat dilakukan suatu upaya hukum. Adapun upaya hukum yang dapat ditempuh oleh perusahaan tersebut adalah melalui jalur pengadilan maupun di luar pengadilan. Hal ini disesuaikan dengan perjanjian yang telah dibuat kedua belah pihak dalam hal penyelesaian perselisihan sehubungan dengan pelaksanaan perjanjian tersebut. Upaya hukum di luar pengadilan dapat ditempuh melalui suatu penyelesaian sengketa alternatif, yaitu dengan melakukan negosiasi, mediasi, konsilisiasi maupun arbitrase. Sedangkan melalui pengadilan dapatmelaluipengajuan gugatan wanprestasi atau gugatan perbuatan melanggar hukum.

Pelanggaran non-competition clause erat kaitannya dengan pelanggaran rahasia dagang. Jika seorang pekerja melakukan pelanggaran rahasia dagang (pengusaha) antara lain melalui lembaga peradilan umum baik itu secara perdata maupun pidana melalui arbitrase, atau menggunakan alternatif penyelesaian sengketa. ${ }^{18}$ Dengan demikian terhadap pelanggaran klausula ini dapat diajukan upaya hukum, baik melalui jalur perdata dan juga pidana.

\section{Pelanggaran suatu non-competition} clause terjadi ketika pekerja tersebut melakukan suatu perbuatan yang dapat merugikan perusahaan, diantaranya pengungkapan informasi yang bersifat rahasia maupun rahasia dagang kepada

\footnotetext{
${ }^{18}$ www.blog.mybcshop.com, op.cit
} 
pihak lain tanpa sepengetahuan pemilik informasi. Kewajiban pekerja tersebut berkaitan dengan kewajiban untuk tidak membocorkan rahasia dagang yang diatur dalam UU Rahasia Dagang. Selain itu perbuatan melanggar hukum yang dilakukan oleh pekerja tersebut juga melanggar hak dari perusahaan, hak di sini terkait dengan hak kekayaan intelektual.

Dengan adanya perbuatan melanggar hukum tersebut, perusahaan menderita kerugian, dan kerugian tersebut merupakan akibat dari pelanggaran non-competition clause yang di lakukan oleh pekerja. Kerugian tersebut terjadi karena kesalahan dari pekerja tersebut. Dengan adanya hubungan kausalitas diantara unsur-unsur dalam perbuatan melanggar hukum tersebut, makagugatan perusahaan berdasarperbuatan melanggar hukum ini dapat berhasil terhadap pelanggaran non-competition clause.

\section{Upaya Pekerja terhadap Pemberlakuan Non-Competition Clause}

Keberlakuan non-competition clause merupakan keberlakuan yang tidak mutlak, karena jika klausula tersebut diberlakukan tanpa ada pembatasan dan hal tersebut terlalu membatasi hak dari pekerja, maka klausula tersebut tidak bisa diberlakukan sehingga tidak mempunyai daya mengikat terhadap pekerja. Tidak adil rasanya jikalau dalam kaitannya dengan klausula ini tidak diberikan suatu perlindungan terhadap pekerja. Jadi tidak serta merta jika klausula ini tidak dipenuhi oleh pekerja, hal tersebut merupakan suatu pelanggaran yang dapat dituntut di depan pengadilan oleh perusahaan. Hal ini dikarenakan harus ada keseimbangan antara kepentingan dari pekerja dan perusahaan.

Jika non-competition clause dirasa sangat membatasi hak pekerja atau dengan kata lain klausula ini tidak dalam batas kewajaran, pekerja tersebut mempunyai hak untuk mengajukan keberatan. Pekerja dapat mengajukan gugatan ke Pengadilan Negeri setempat. Isi dari gugatan tersebut antara lain berisi keberatan atas isi dari Perjanjian Persaingan dan memohon kepada Hakim untuk membatalkan isi dari Perjanjian Persaingan tersebut. ${ }^{19}$ Hal ini diatur dalam Pasal 1601 x ayat (2) BW yang menyatakan bahwa :

"Pengadilandiperbolehkanatastuntutan buruh walaupun karena dimintanya pada pembelaannya dalam suatu perkara, meniadakan untuk seluruhnya atau sebagian suatu janji seperti itu dengan alasan bahwa dibandingkan dengan kepentingan majikan yang dilindungi itu, buruh dirugikan secara tidak adil oleh janji tersebut".

Non-competition clause berlaku ketika hubungan kerja telah berakhir. Berakhirnya hubungan kerja tersebut dikarenakan pekerja mengundurkan diri atas kemauannya sendiri atau melalui suatu pemutusan hubungan kerja. Dalam Pasal 1601 x ayat (2) BW dinyatakan bahwa :

"Majikan tidak dapat memperoleh hak dari suatu janji sebagai yang dimaksud pada ayat kesatu, jika ia telah mengakhiri hubungankerja secaramelanggarhukumatau

\footnotetext{
${ }^{19}$ Djumadi, op.cit, h.75
} 
ia dengan sengaja atau karena kesalahannya telah memberi alasan mendesak kepada buruh untuk mengakhiri hubungan kerja dan buruh ini telah menggunakan wewenang itu, atau jika Pengadilan atas permintaan atau gugatan buruh telah menyatakan putusnya hubungan kerja berdasarkan alsan mendesak, yang diberikan kepada buruh karena kesengajaan atau kesalahan majikan."

Mengenai keberatan terhadap noncompetition clause ini dapat dikategorikan sebagai perselisihan kepentingan sebagaimana yang dimaksud dalam Pasal 1 angka 3 Undang-undang Nomor 2 Tahun 2004 tentang Penyelesaian Perselisihan Hubungan Industrial (selanjutnya disebut sebagai UU PPHI). ${ }^{20}$ Perselisihan ini wajib diupayakan terlebih dahulu melalui perundingan bipartit secara musyawarah untuk mencapai mufakat. Kemudian jika perundingan bipartit tersebut gagal, maka salahsatuataukeduabelahpihakmencatatkan perselisihannya kepada instansi yang bertanggungjawabdibidangketenagakerjaan setempat. Instansi yang bertanggung jawab di bidang ketenagakerjaan setempat wajib menawarkan kepada para pihak untuk menyepakati memilih penyelesaian melalui konsiliasi atau arbitrase. Dalam hal para pihak tidak menetapkan pilihan penyelesaian melalui konsiliasi atau arbitrase, maka penyelesaian perselisihan ini dilimpahkan kepada mediator. Jika tidak mencapai kesepakatan, maka salah satu pihak dapat mengajukan gugatan kepada Pengadilan Hubungan Industrial.

\section{Kesimpulan}

Tidak setiap perjanjian kerja memuat suatu non-competition clause di dalamnya. Pencantuman non-competition clause dilatarbelakangi oleh kepentingan perusahaan terhadap perlindungan hak kekayaan intelektual dalam hal ini rahasia dagang maupun hal-hal lain yang menyangkut kepentingan perusahaan terhadap perusahaan pesaingnya. Di sisi lain, klausula ini bersinggungan dengan hak dari pekerja yaitu hak untuk memilih, mendapatkan, atau pindah pekerjaan dan memperoleh penghasilan yang layak di dalam dan atau di luar negeri. Dengan adanya pertentangan kepentingan tersebut, keberlakuan suatu non-competition clause sah apabila terdapat pembatasan terhadap periode waktu dan wilayah geografis serta pemberian kompensasi bagi pekerja dalam pelaksanaan klausula tersebut.

Pekerja dikategorikan melakukan pelanggaranterhadapnon-competitionclause apabila pekerja mengungkapkan informasi perusahaan yang meliputi segala informasi yang bersifat rahasia maupun rahasia dagang tanpa sepengetahuan perusahaan pemilik informasi untuk kepentingan perusahaan baru tempat ia bekerja sehingga menimbulkan kerugian bagi perusahaan lama tempat ia bekerja sebelumnya. Adapun upaya hukum yang dapat ditempuh oleh perusahaan yang dirugikan yaitu melalui penyelesaian di pengadilan atau di luar pengadilan. Bagi pekerja yang dirugikan akibat adanya klausula ini dapat melakukan suatu upaya hukum yaitu pengajuan

${ }^{20}$ Lihat Pasal 1 angka 3 UU PPHI 
pembatalan perjanjian.

Perlu adanya suatu pengaturan secara spesifik mengenai pencantuman noncompetition clause sehingga dapat diperoleh kepastian hukum yang jelas bagi pekerja dan perusahaan sehingga tidak terjadi benturan kepentingan antara kedua belah pihak tersebut. Untuk menentukan pengaturan beserta pembatasan terhadap pemberlakuan klausula ini, dapat dilakukan kajian terhadap aturan-aturan dan pembatasanpembatasan yang telah ada pada beberapa Negara di dunia baik Negara-negara Civil Law maupun Common Law. Pengkategorian yang lebih jelas mengenai pelanggaran noncompetition clause baik yang dilakukan oleh pekerja maupun perusahaan juga diperlukan sehingga dapat lebih mudah dalam penyelesaianya. Hal ini diperlukan agar kedua belah pihak tidak menyalahgunakan perjanjian tersebut yang akan membawa kerugian bagi masing-masing pihak.

\section{DAFTAR PUSTAKA}

Djumadi, Hukum Perburuhan Perjanjian Kerja, Raja Grafindo Persada, Jakarta, 2008

Jened, Rahmi, "Perlindungan "Trade Secret" (Rahasia Dagang) dalam Rangka

Persetujuan TRIPs".
Kurniawan, Chandra, "Menyoal Non Competition Clause dalam Perjanjian Kerja”, diakses melalui www. purcahyo.blogspot.com

Rusli, Hardijan, Hukum Ketenagakerjaan, Ghalia Indonesia, Jakarta, 2004

Subekti, Hukum Perjanjian, Intermasa, Jakarta, 2005

Undang-Undang Dasar Negara Republik Indonesia Tahun 1945;

Undang-Undang Nomor 39 Tahun 1999 tentang Hak Asasi Manusia (Lembaran Negara Republik Indonesia Tahun 1999 Nomor 165, Tambahan Lembaran Negara Republik Indonesia Nomor 3886);

Undang-Undang Nomor 30 Tahun 2000 tentang Rahasia Dagang (Lembaran Negara Republik Indonesia Tahun 2000 Nomor 242, Tambahan Lembaran Negara Republik Indonesia Nomor 4044);

Undang-Undang Nomor 13 Tahun 2003 tentang Ketenagakerjaan (Lembaran Negara Republik Indonesia Tahun 2003 Nomor 39, Tambahan Lembaran Negara Republik Indonesia Nomor 4279);

Undang-Undang Nomor 2 Tahun 2004 tentang Penyelesaian Perselisihan Hubungan Industrial (Lembaran Negara Republik Indonesia Tahun 2004 Nomor 6, Tambahan Lembaran Negara Republik Indonesia Nomor 4356); 
128 Yuridika: Volume 26 No 2, Mei-Agustus 2011 